\title{
Effect of intramedullary nail compression amount on the union process of tibial shaft fracture and the evaluation of this effect with a different parameter
}

\author{
Tibia cisim kırıklarında intramedüller çivi kompresyon miktarının kırık kaynaması üzerine etkisi ve \\ farklı bir parametre ile değerlendirilmesi
}

\author{
Fatih Duygun (D, MD, Cengiz Aldemir (D), MD. \\ Department of Orthopedics and Traumatology, University of Health Sciences, Antalya Training and Research Hospital, Antalya, Turkey
}

\begin{abstract}
Objectives: This study aims to investigate the effects of different amounts of compression used in intramedullary nailing on the stress values of the fracture surface and time of the union process in tibia diaphysis fractures treated with intramedullary nails.

Patients and methods: Seventy patients (50 males, 20 females; mean age $34.0 \pm 10.7$ years; range, 20 to 56 years) who had suffered from tibial shaft fractures between January 2007 and December 2015 were included in the study. Patients who had A2, A3, and B2 type fractures according to $\mathrm{AO}$ (Arbeitsgemeinschaft für Osteosynthesefragen) classification and those with closed fractures were included. The patients were divided into three groups. No compression was applied to Group A, dynamic compressive fixation intramedullary nailing was applied to Groups B and C. Amount of applied compression was $1 \mathrm{~mm}$ for Group B and $1.5 \mathrm{~mm}$ for Group C. Postoperative and follow-up radiographs of patients were evaluated according to Rust criteria, and functional results were evaluated according to Johner-Wrush criteria. Additionally, finite element analyses were performed separately for $1 \mathrm{~mm}$ and $1.5 \mathrm{~mm}$ compressions that were applied in Group B and C, respectively. The data were analyzed using a statistical software package.
\end{abstract}

Results: Clinical and radiological union was achieved in all patients. The average time of radiological union was $15.05 \pm 2.06$ weeks in Group A, $12.48 \pm 1.42$ weeks in Group B, and $11.64 \pm 1.63$ weeks in Group C. The time of union for the group in which no compression was applied (Group A) was significantly longer than the other groups in which compression was applied (Group B and C) $(\mathrm{p}<0.001)$. Functional outcomes were 17 patients $(85 \%)$ with excellent and three patients $(15 \%)$ with goodmoderate results in Group A, 23 (92\%) excellent and two (8\%) goodmoderate in Group B, and 23 (92\%) excellent and two patients (8\%) with good-moderate results in Group C. In total, seven patients had knee pain. No infection was seen in any patient.

Conclusion: Interlocking compression intramedullary nailing is a very effective treatment method for tibial shaft fractures. As the compression applied by the nail increases, the time of union shortens significantly.

Keywords: Compression; fracture union; intramedullary nail; tibial shaft fractures.
ÖZ

Amaç: Bu çalışmada intramedüller çivi uygulanan tibia diafiz kırı̆̆ı olgularında farklı kompresyon miktarlarının kırık yüzeyindeki stres değerlere etkisi ve kaynama süreleri arasındaki ilişki araştırıldı.

Hastalar ve yöntemler: Ocak 2007 - Aralık 2015 tarihleri arasında tibia cisim kırığı olan 70 hasta $(50$ erkek, 20 kadın; ort. yaş $34.0 \pm 10.7$ yıl; dağılım, 20-56 yıl) çalışmaya alındı. AO (Arbeitsgemeinschaft für Osteosynthesefragen) sınıflamasına göre A2, A3 ve B2 tip kapalı kırık olan hastalar çalışmaya alındı. Hastalar üç gruba ayrıldı. Grup A'da kompresyon yapılmadı, Grup B ve C'de intramedüller çivi ile dinamik kompressif tespit yapıldı. Uygulanan kompresyon miktarı grup B'de $1 \mathrm{~mm}$, grup C'de $1.5 \mathrm{~mm}$ idi. Hastaların ameliyat sonrası ve takip radyografileri Rust kriterlerine göre, fonksiyonel sonuçlar ise Johner-Wrush kriterlerine göre değerlendirildi. Ayrıca Grup B ve grup C'de sırasıyla $1 \mathrm{~mm}$ ve $1.5 \mathrm{~mm}$ için ayrı ayrı uygulanan kompresyon ile ilgili sonlu eleman çalışması yapıldı. Veriler istatistisel paket yazılım programıyla analiz edildi.

Bulgular: Bütün hastalarda klinik ve radyolojik olarak kaynama elde edildi. Radyolojik kaynama grup A'da ortalama $15.05 \pm 2.06$ haftada, grup B'de $12.48 \pm 1.42$ haftada ve grup C'de $11.64 \pm 1.63$ haftada sağlandığ 1 görüldü. Kompresyon uygulanmayan grupta (Grup A) kaynama süresi, kompresyon uygulanan diğer gruplara göre (Grup B ve C) anlamlı düzeyde uzundu $(\mathrm{p}<0.001)$. Fonksiyonel sonuçlar grup A'da 17 hastada (\%85) mükemmel, üç hastada (\%15) iyi-orta, grup B'de 23 hastada (\%92) mükemmel, iki hastada $(\% 8)$ iyi-orta, grup C'de 23 hastada (\%92) mükemmel, iki hastada (\%8) iyi-orta olarak değerlendirildi. Toplam yedi hastada diz önü ağrısı vard1. Hiçbir hastada enfeksiyon görülmedi.

Sonuç: İntramedüller kilitli kompressif çiviler tibia cisim kırıklarında oldukça etkin bir tedavi yöntemidir. Çivi üzerinden uygulanan kompresyon arttıkça, kaynama süresi anlamlı şekilde kısalmaktadır.

Anahtar sözcükler: Kompresyon; kırık kaynaması; intramedüller çivi; tibia cisim kırığı.

Received: March 02, 2018 Accepted: May 21, 2018

Correspondence: Fatih Duygun, MD. Sağlık Bilimleri Üniversitesi Antalya Eğitim ve Araştırma Hastanesi Ortopedi ve Travmatoloji Kliniği, 07ı0 Antalya, Turkey. Tel: +90533 - 7176231 e-mail: fduygun2000@yahoo.com 
Every year, tibia diaphysis fractures occur at a rate of 26/100,000. ${ }^{[1]}$ These fractures are accompanied by severe soft tissue injuries, malunion, nonunion, and infection at high rates. ${ }^{[2]}$ Unstable tibia shaft fractures require surgical treatment. ${ }^{[3]}$ Intramedullary nailing (IMN) is currently a widely used treatment modality in tibia fractures and provides superior functional outcome compared to conservative treatment ${ }^{[4,5]}$ and provides sufficient mechanical stability with better fracture alignment. ${ }^{[6]}$ Interlocking nails may be applied via various approaches such as reamed and unreamed, compressive and non-compressive, and also static, dynamic, and dynamic-compressive interlocking. Active compression of the fracture line accelerates fracture union. ${ }^{[7]}$

In our study, we investigated the effects of various amounts of compression on fracture union time in patients who were treated with IMN for tibia diaphysis fractures. In addition, via finite element study, we evaluated the stress values on the fracture surface due to the compression applied.

\section{PATIENTS AND METHODS}

Seventy patients (50 males, 20 females; mean age $34.0 \pm 10.7$ years; range, 20 to 56 years) who had suffered from tibial shaft fractures between January 2007 and December 2015 were examined retrospectively. Only closed fractures and the patients with type A2, A3, and B2 fractures according to AO (Arbeitsgemeinschaft für Osteosynthesefragen) classification were included in the study. Regarding patient groups, those with similar fracture types were selected. Patients with comorbidities were excluded from the study. The patients were examined every 15 days following their discharge from the hospital. The study protocol was approved by the Antalya Training and Research Hospital Ethics Committee. The study was conducted in accordance with the principles of the Declaration of Helsinki.

Patients were divided into three groups. Group A consisted of patients who were treated without compression, Group B consisted of patients who received $1 \mathrm{~mm}$ of compression, and Group $C$ patients underwent $1.5 \mathrm{~mm}$ of compression. In Group A, the nails were applied as static locked without compression after reaming (C75, OrthoFix, TipMed, Smith \& Nephew). In the patients in Groups B and $\mathrm{C}$, intramedullary compression nail was applied, and dynamic compressive locking was performed following reaming. In all cases, intramedullary compressive nail (IMCN) was applied following the reaming procedure. Maximum bone contact was then manually achieved between proximal and distal bone fragments; dynamic compressive fixation with $1 \mathrm{~mm}$ of compression was performed by a single rotation, and $1.5 \mathrm{~mm}$ compression was performed by a 1.5 turn of the compression screw at the top of the nail.

No splints or braces were used postoperatively. All patients used antiembolic stockings for four weeks. Low-molecular-weight-heparin was administered until mobilization of the patient. Cefazolin sodium was used intravenously with a dose of $1 g \times 4$ times a day, for 24 hours. Patients' radiographs were taken, and clinical evaluations were performed postoperatively and during follow-up. The direct X-ray graphs were evaluated according to Rust criteria, and the functional results were evaluated according to Johner - Wrush criteria. Finite element analyses were performed for $1 \mathrm{~mm}$ and $1.5 \mathrm{~mm}$ of compression. For statistical analysis, one-way ANOVA, Fisher's exact test, Pearson's chi-square, Mann-Whitney U test and Student's T-test were used.

\section{Surgical procedure}

Patients were prepared in the supine position with the fractured extremity loose from the knee. The patellar tendon was longitudinally cut in all patients, and transtendinous access was obtained. Following reduction, the tibia was reamed using proximal superior access. The appropriate diameter and length of the nail were determined, and nailing was performed while taking measure to keep the nail lower than the level of the anterior edge of the tibial plateau when the top screw was placed. Distal locking was done with two interlocking screws. Locking was achieved with one screw through the proximal dynamic hole for Groups B and C. Locking was performed without fluoroscopy, by the technique described previously. ${ }^{[8]}$ The compression screw was applied from the proximal of the nail contacted with the interlocking screw, which passed through the dynamic hole. Compression was applied by turning the screw one turn for $1 \mathrm{~mm}$, and 1.5 turn for $1.5 \mathrm{~mm}$ of compression. For group A, all screws at the proximal site were statically locked. The process was completed by application of a top screw.

\section{Statistical analysis}

Descriptive statistics were presented as "mean \pm standard deviation (SD)," "median (min-max)" and "n (\%)" values, when appropriate. Fisher's exact test and Pearson's chi-square analyses were performed for categorical variables. Student's T-test was used for comparison of two groups, and one-way ANOVA was used for comparison of three groups with a normal distribution. Mann-Whitney $U$ test was used for comparison of quantitative variables with 

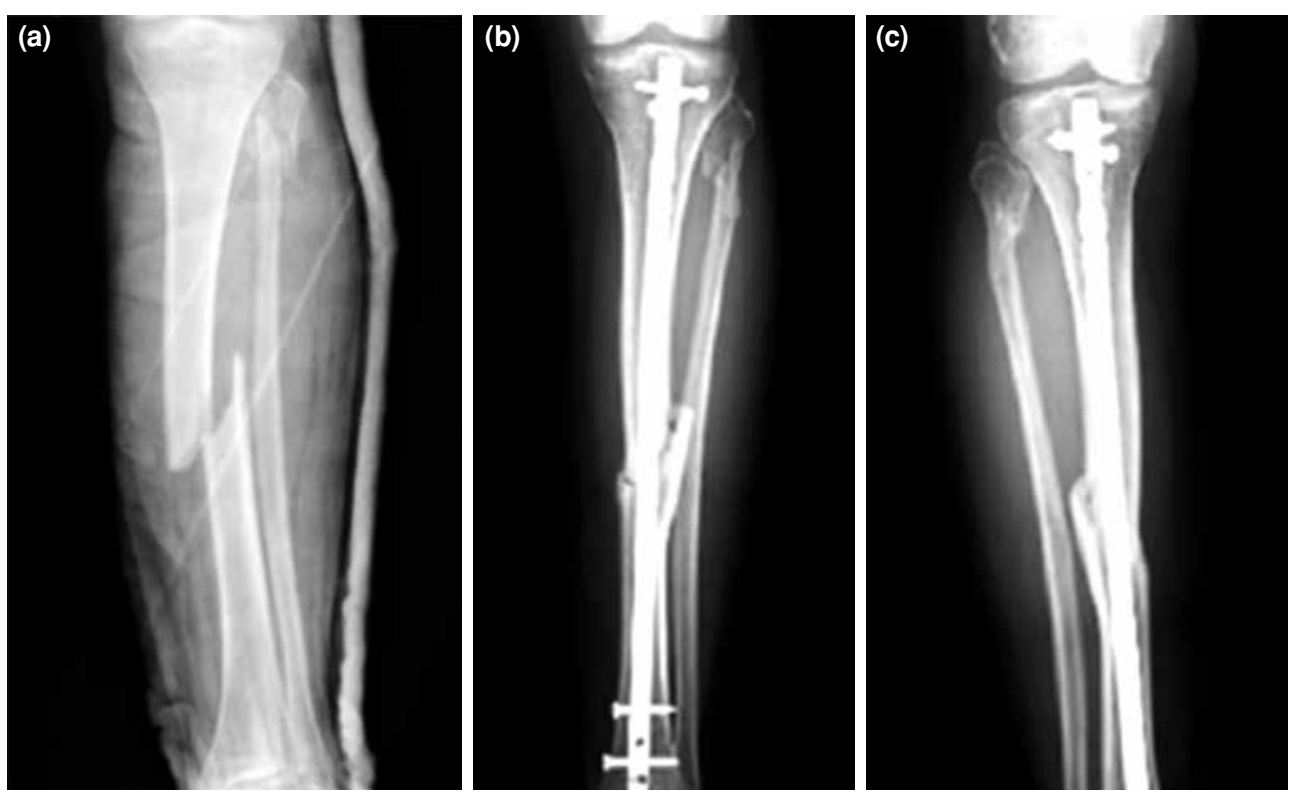

Figure 1. (a) Preoperative anteroposterior view of the left tibia of a 43-year-old woman. (b, c) Same patient, postoperative 18 and 24 weeks, anteroposterior view. No compression was applied.

non-normal distribution. Statistical analysis was performed using the IBM SPSS for Windows, version 21.0 software (IBM Corp., Armonk, New York, USA). A $p$ value $<0.05$ was considered statistically significant.

\section{Finite element analysis}

Two types of material were used in analyses. The first was the cortical bone material which was identified according to bone data. The mechanical properties of the bone material were determined as follows: elasticity module: $20 \mathrm{GPa}$, Poisson ratio: 0.15 , and density: $1,650 \mathrm{~kg} / \mathrm{m}^{3}$. The material that the nails and screws were made of was titanium. The mechanical properties of titanium were determined as follows: elasticity module: $96 \mathrm{GPa}$, Poisson ratio: 0.36, density: $4,620 \mathrm{~kg} / \mathrm{m}^{3}$.

\section{RESULTS}

Union was achieved in all patients (Figures $1 \mathrm{a}, \mathrm{b}, 2 \mathrm{a}$, $b, 3 a, b)$. The average bone union times are shown in Table 1, Figure 4. The average radiological union
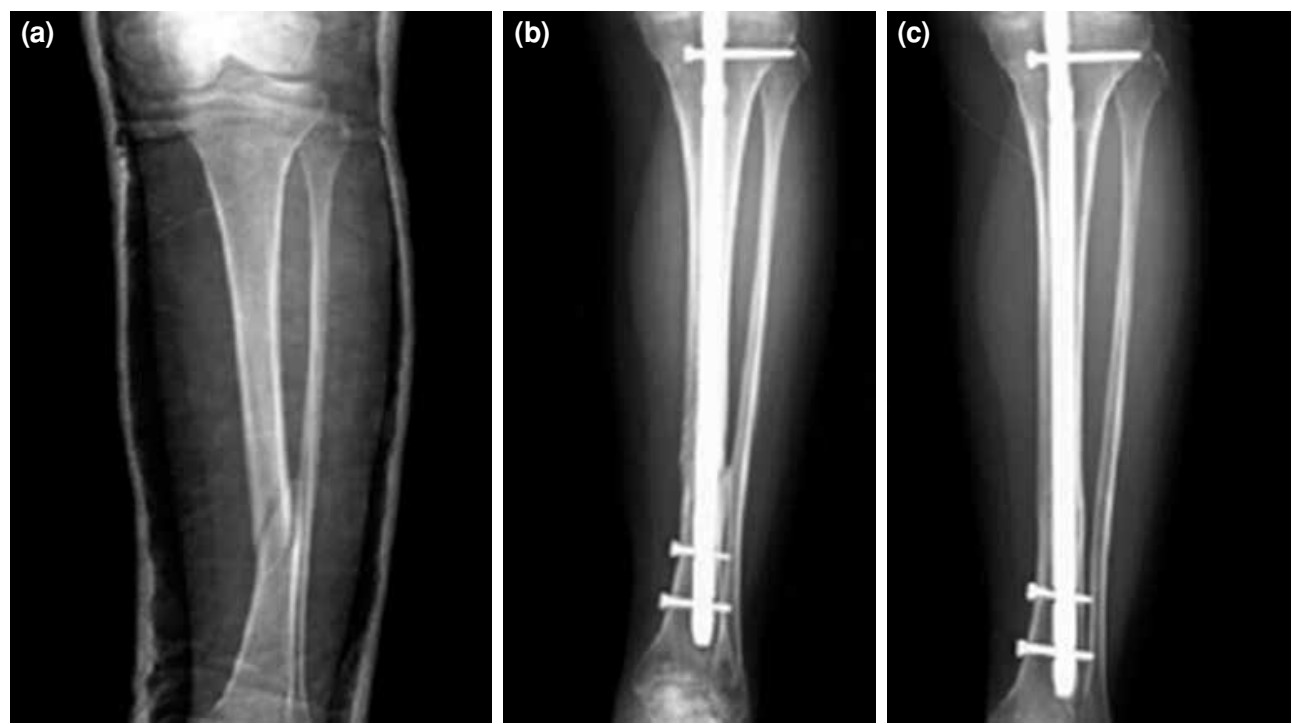

Figure 2. (a) Preoperative anteroposterior view of the left tibia of a 43-year-old woman. (b, c) Same patient, postoperative 16 and $20^{\text {th }}$ weeks, anteroposterior view. $1 \mathrm{~mm}$ compression was applied. 

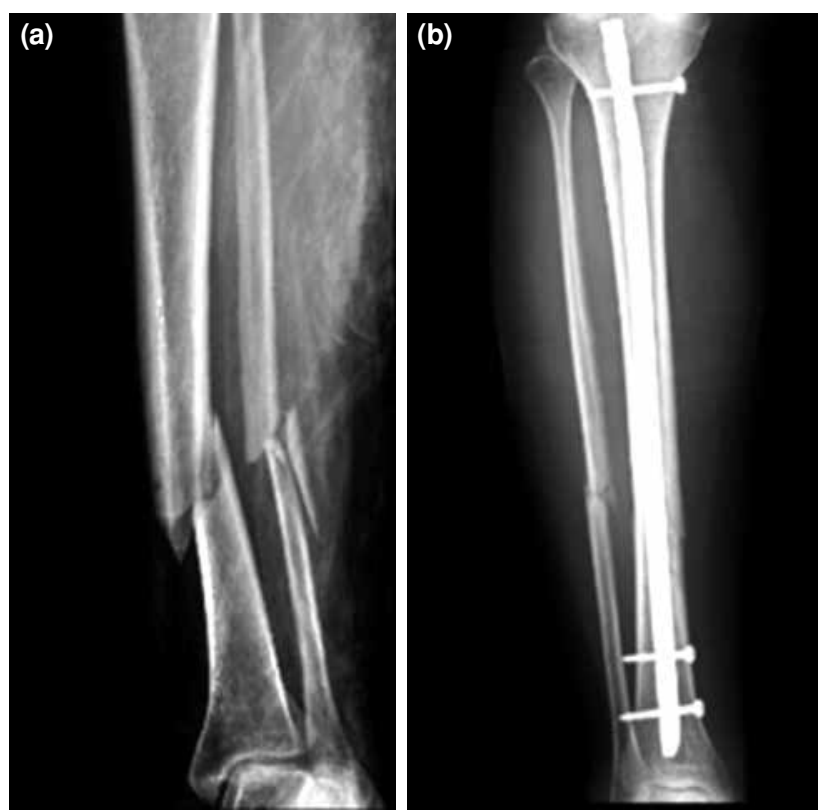

Figure 3. (a) Preoperative anteroposterior view of right tibia a 38-year-old man. (b) Same patient, postoperative $12^{\text {th }}$ weeks, anteroposterior view of the left tibia. $1.5 \mathrm{~mm}$ compression was applied.

times were $15.05 \pm 2.06)$ weeks in Group A, 12.48 \pm 1.42 ) weeks in Group B, and 11.64 \pm 1.63 ) weeks in Group C. The time of union for the group in which compression was not applied (Group A) was significantly longer than the other groups in which compression was applied (Group B and C) $(\mathrm{p}<0.001)$. There was no statistically significant difference between the patient groups in which $1 \mathrm{~mm}$ and $1.5 \mathrm{~mm}$ of compression were applied (Group B and C).

Evaluation of functional outcomes showed that 17 patients $(85 \%)$ were excellent, and three patients $(15 \%)$ were good-to-moderate in Group A. Twenty three patients $(92 \%)$ had excellent, and two patients $(8 \%)$ had good-to-moderate outcomes in Group B and 23 patients $(92 \%)$ were excellent, two patients $(8 \%)$ were good-to-moderate in Group C. In total, seven patients had anterior knee pain. None of the patients suffered from infection, compartment syndrome,

TABLE I

Comparison of time to bony union values of study groups

\begin{tabular}{lcc}
\hline & Time to bony union & \\
\cline { 2 - 2 } & Mean \pm SD & $p$ \\
\hline Non-compression & $15.1 \pm 2.1$ & \\
$1 \mathrm{~mm}$ compression & $12.5 \pm 1.4$ & $<0.001$ \\
$1.5 \mathrm{~mm}$ compression & $11.6 \pm 1.6$ & \\
\hline
\end{tabular}

or clinical thromboembolism. According to finite element analysis, average stress values were $43 \mathrm{Mpa}$ in Group B and 51 Mpa in Group C.

\section{DISCUSSION}

Interlocked compression intramedullary nailing shortens the duration of fracture union in patients with tibial shaft fractures. ${ }^{[9,10]}$ In our study, the duration of the union was found to be shorter in Groups B and C, in which compression was applied, compared to Group A which was the non-compression group. There was no statistically significant difference between Group B and Group C in regarding the union time. Therefore, we do not believe it is necessary to apply more compression to the $\mathrm{AO}$ type $\mathrm{A} 2, \mathrm{~A} 3$, and $\mathrm{B} 2$ tibia shaft fractures.

Högel et al. ${ }^{[7]}$ studied the force value between the compression screw placed on the proximal portion of the intramedullary nail and the bone fixation screw. While the average compression load was $1.852 \mathrm{~N}$ (362-4.325) during the postoperative phase, the average compression load was measured as $980 \mathrm{~N}$ (188-2.550) four weeks after the operation. Högel et al. ${ }^{[7]}$ did not mention the stress value of the fracture surface in their study. We performed finite element study because we believe that the stress value on the fracture surface is a more realistic representation of stress. In our study, the pressure distribution on the tibia fracture site was calculated based on different amounts of compression ( $1 \mathrm{~mm}$, and $1.5 \mathrm{~mm})$. This pressure distribution can be attributed to the load caused on the fracture site by the bending moment of this force, in addition to the axial force mentioned in Högel's study.

In another study, Baki et al. ${ }^{[11]}$ demonstrated the effects of different compression amounts on fracture union in an experimental study on rabbits in which

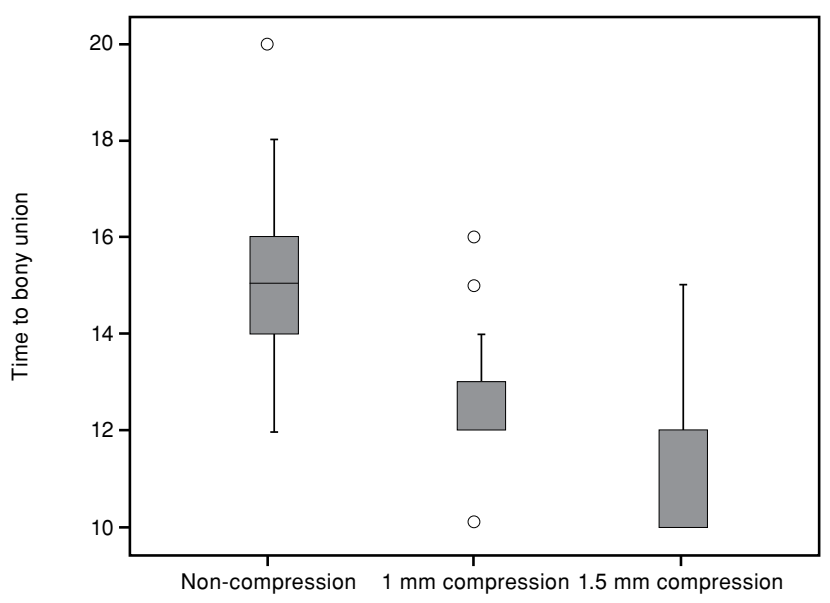

Figure 4. Comparison bone union times of study groups. 


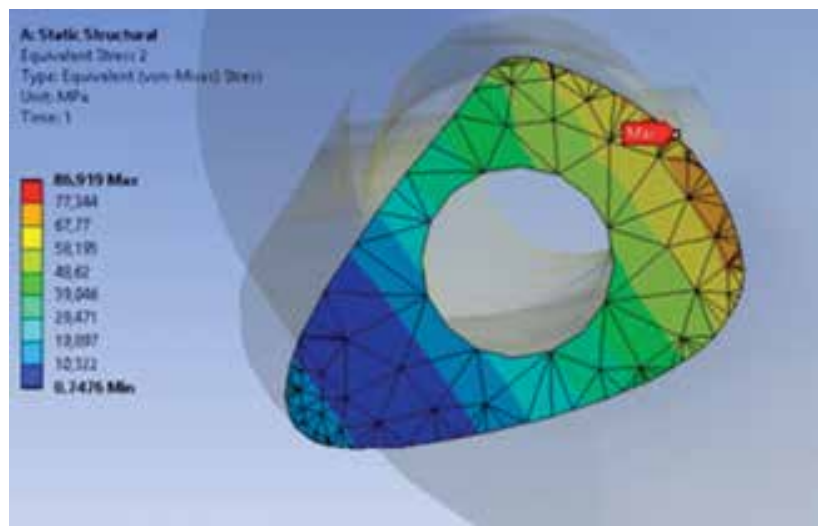

Figure 5. Stress value on the fracture surface when $1.0 \mathrm{~mm}$ intramedullary nail compression is applied.

they introduced 0.5 and $1 \mathrm{~mm}$ of compression on the fracture surface and performed finite element studies. They reported that $0.5 \mathrm{~mm}$ of compression resulted in a stress value of $34.5 \mathrm{MPa}$, while this value was $88 \mathrm{MPa}$ for $1 \mathrm{~mm}$ of compression. They also found that union was histologically better and was obtained sooner in the 34.5 Mpa group. In our endpoint study, we obtained mean stress values of $34 \mathrm{MPa}$ with $1 \mathrm{~mm}$ compression and $51 \mathrm{MPa}$ with $1.5 \mathrm{~mm}$ compression (Figure 5, 6).

The tibia does not have a curved structure; therefore, when the tibia is exposed to axial load and deforming forces, its stress values change linearly (for example, $34 \mathrm{MPa}$ for a $1 \mathrm{~mm}$ compression, $51 \mathrm{MPa}$ for a $1.5 \mathrm{~mm}$ compression). However, in the femur, due to its anatomical curve, stress values of different anatomic regions of the fracture show a nonlinear relationship (34.5 MPa at $0.5 \mathrm{~mm}$ compression, $88 \mathrm{MPa}$ at $1 \mathrm{~mm}$ compression). In humerus body fracture, $1 \mathrm{~mm}$ of compression was found to result in an average stress value of $50 \mathrm{MPa} .{ }^{[12]}$ Because of the fact that anatomical slopes and fracture surface areas of the bones vary, the stress values obtained with the same amount of compressions in the humerus, femur, and tibia differ in finite element studies. ${ }^{[11,12]}$ According to our clinical results and the experimental studies of Baki et al., ${ }^{[11]}$ optimal compression is the amount of compression which produces a stress value between 34 and $88 \mathrm{MPa}$. We believe that the MPa parameter, which shows surface stress tension, is more important than the millimeter and Newton parameters, which show compression.

While some authors suggest backstroke, Mückley et al. ${ }^{[13]}$ reported that compression was superior to the Back-Stroke method, which is the exertion of force in the opposite direction following insertion of the distal screws and achieving contact of the bone edges,

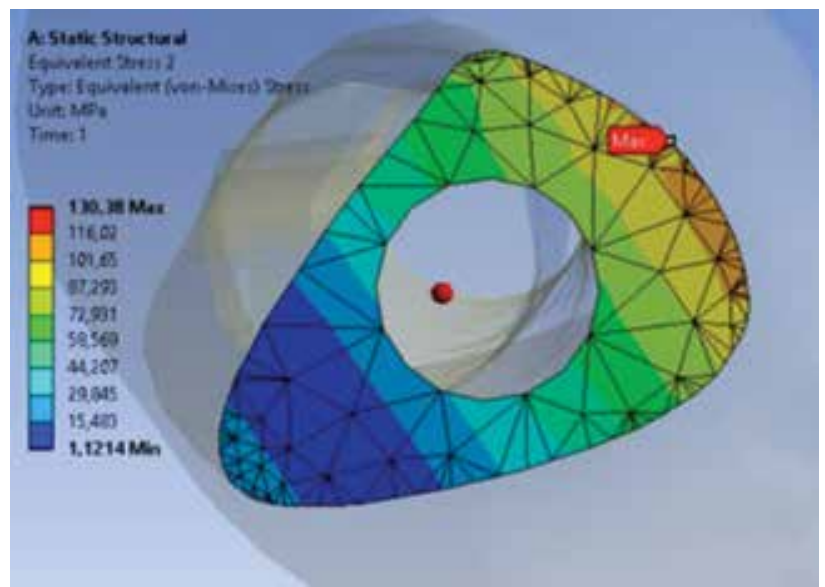

Figure 6. Stress value on the fracture surface when $1.5 \mathrm{~mm}$ intramedullary nail compression is applied.

in providing initial stability. ${ }^{[13]}$ We did not perform Back-Stroke in any of our patients whose reduction was complete.

Numerous authors have mentioned anterior knee pain after application of intramedullary nailing in tibial shaft fractures and have reported different rates. ${ }^{[14-17]}$ We found that anterior knee pain was present in seven $(10 \%)$ of our cases. Those with knee pain were the patients in which the nail was higher than desired. The knee pain was unrelated to the compressive or non-compressive nature of the application. No infection was seen in any of the patients.

\section{Limitations}

Our study is a retrospective study focused on only tibial shaft fractures and two different compression amounts. Due to differences in surface structure, further studies are necessary to evaluate proximal and distal fractures. Using nails with different brand names was one of the negative aspects of our study.

\section{Conclusion}

Interlocking compression nailing significantly shortens the duration of the union in the AO, A2, $\mathrm{A} 3$, and $\mathrm{B} 2$ types of tibial shaft fractures. There is no statistically significant difference between the $1 \mathrm{~mm}$ and 1.5 compressions regarding the duration of the union. We believe that stress value on fracture surfaces is an important parameter among the loading that is used to evaluate compression load.

To our knowledge, this is the first study in which both compression and fracture surface stress values in the treatment of tibial shaft fractures are studied together in humans. 


\section{Declaration of conflicting interests}

The authors declared no conflicts of interest with respect to the authorship and/or publication of this article.

\section{Funding}

The authors received no financial support for the research and/or authorship of this article.

\section{REFERENCES}

1. Egol AK, Koval KJ, Zuckerman DJ. Lower extremity fractures and dislocations. In: Egol AK, Koval KJ, Zuckerman DJ, editors. Handbook of Fractures. 4th ed. Philadelphia: Lippincott Williams \& Wilkins;2010. p. 464-75.

2. Gaebler C, McQueen MM, Vécsei V, Court-Brown CM.Reamed versus minimally reamed nailing: a prospectively randomised study of 100 patients with closed fractures of the tibia. Injury 2011;42:17-21.

3. Whittle AP, Wood GW. Fractures of lower extremity. In: Canal ST, editor. Campbell's Operative Orthopedics. 10th ed. Philadelphia: Elsevier; 2003. p. 2726-858.

4. Yasuda T, Obara S, Hayashi J, Arai M, Sato K.Semiextended approach for intramedullary nailing via a patellar eversion technique for tibial-shaft fractures: Evaluation of the patellofemoral joint. Injury 2017;48:1264-8.

5. Petrisor BA, Bhandari M, Schemitsch E. Tibia and fibulae fractures. In: Bucholz RW, Heckman JD, Court-Brown CM, Tornetta P, editors. Rockwood and Green's Fractures in Adults. 7th ed. Philadelphia: Lippincott, Williams \& Wilkins; 2010. p. 1880-2.

6. Mukherjee S, Arambam MS, Waikhom S, Santosha, Masatwar PV, Maske RG. Interlocking nailing versus plating in tibial shaft fractures in adults: A comparative study. J Clin Diagn Res 2017;11:8-13.

7. Högel F, Gerber C, Bühren V, Augat P. Reamed intramedullary nailing of diaphyseal tibial fractures: comparison of compression and non-compression nailing. Eur J Trauma Emerg Surg 2013;39:73-7.

8. Aldemir C, Doğan A, Inci F, Sertkaya O, Duygun F. Distal locking techniques without fluoroscopy in intramedullar nailing. Eklem Hastalık Cerrahisi 2014;25:64-9

9. Gupta A. Dynamic compression nail: a preliminary report. BMC Musculoskelet Disord 2001;2:6.

10. Gonschorek O, Hofmann GO, Bühren V. Interlocking compression nailing: a report on 402 applications. Arch Orthop Trauma Surg 1998;117:430-7.

11. Baki ME, Aldemir C, Duygun F, Doğan A, Kerimoğlu G. Comparison of non-compression and compression interlocking intramedullary nailing in rabbit femoral shaft osteotomy model. Eklem Hastalik Cerrahisi 2017;28:7-12.

12. Duygun F, Aldemir C. Is locked compressive intramedullary nailing for adult humerus shaft fractures advantageous? Eklem Hastalik Cerrahisi 2017;28:80-6.

13. Mückley T, Diefenbeck M, Sorkin AT, Beimel C, Goebel M, Bühren V. Results of the T2 humeral nailing system with special focus on compression interlocking. Injury 2008;39:299-305.

14. Song SY, Chang HG, Byun JC, Kim TY. Anterior knee pain after tibial intramedullary nailing using a medial paratendinous approach. J Orthop Trauma 2012;26:172-7.

15. Toivanen JA, Väistö O, Kannus P, Latvala K, Honkonen $\mathrm{SE}$, Järvinen MJ.Anterior knee pain after intramedullary nailing of fractures of the tibial shaft. A prospective, randomized study comparing two different nail-insertion techniques. J Bone Joint Surg [Am] 2002;84:580-5.

16. Bhattacharyya T, Seng K, Nassif NA, Freedman I. Knee pain after tibial nailing: the role of nail prominence. Clin Orthop Relat Res 2006;449:303-7.

17. Darabos N, Bajs ID, Rutić Z, Darabos A, Poljak D, Dobsa J. Nail position has an influence on anterior knee pain after tibial intramedullary nailing. Coll Antropol 2011;35:873-7. 